\title{
Impact of Political Instability on Economic Growth in CEE Countries
}

Political instability is often considered to have a negative influence on economic growth. Hence, the study aims to examine whether instability of the political environment (measured by the political stability index and duration of the chief executive in the office) significantly influences economic growth in Central and Eastern European (CEE) countries. The methodology used is a fixed effects model for panel data analysis where the dependent variable is the real growth of gross domestic product (GDP) per capita. The data covers the period from 2006 to 2016 for 13 CEE countries. Additionally, the study considered other macroeconomic variables, such as investment, inflation, human capital, trade openness, etc. The research findings indicate that the political stability index has a positive effect on economic growth, as expected and predicted in the literature. However, the indicator of the years the chief executive has been in the office has shown a negative effect. This effect appears to be weakly significant only for the second variable. These findings allowed us to conclude that the political stability index positively influences economic growth, while the years the chief executive stays in the office has a negative effect. Frequent changes in the cabinet can actually have a positive impact in transition countries characterised by corruption, meaning that the long stay of a chief executive in the office can lead to power abuse.

Keywords: political instability, economic growth, panel data, index of economic freedom, gross capital formation, government expenditure, population growth, inflation, trade openness

For citation: Çela, A. \& Hysa, E. (2021). Impact of Political Instability on Economic Growth in CEE Countries. Ekonomika regiona [Economy of region], 17(2), 582-592, https://doi.org/10.17059/ekon.reg.2021-2-16

${ }^{1}$ (c) Çela A., Hysa E. Text. 2021. 


\author{
А. Жела ${ }^{a)}$, Э. Хиса ${ }^{\text {б) }}$ \\ а, б) Университет Эпока, Тирана, Албания \\ a) https://orcid.org/0000-0001-6201-2152 \\ 6) https://orcid.org/0000-0002-3429-5738, ehysa@epoka.edu.al
}

\section{Влияние политической нестабильности на экономический рост в странах Центральной и Восточной Европы}

\begin{abstract}
Считается, что политическая нестабильность отрииательно влияет на экономический рост. Настоящая статья исследует влияние нестабильности политической среды на экономический рост в странах Центральной и Восточной Европы. Для этой иели были использованы две переменные: индекс политической стабильности и показатель продолжительности пребывания главы правительства на посту. Для анализа была применена модель панельных данных с фиксированными эфбектами, где зависимой переменной является реальный рост валового внутреннего продукта (ВВП) на душу населения. Данные охватывают период с 2006 г. по 2016 г. по 13 странам Центральной и Восточной Европь. Кроме указанных показателей были рассмотрены другие макроэкономические переменные: инвестиции, инфляция, человеческий капитал, открытость торговли и др. Результаты анализа показали, что индекс политической стабильности оказывает положительное влияние на экономический рост, как и прогнозировали исследователи в своих работах. Однако значение показателя продолжительности пребывания главы правительства на посту является отрицательным. Этот эфбект оказался незначительным только для второй переменной. Полученные результаты позволили сделать вывод, что индекс политической стабильности положительно влияет на экономический рост, в то время как продолжительность пребывания главы правительства на посту имеет отрицательный эффект. В странах с переходной экономикой, в которых распространена коррупия, частые изменения в кабинете министров могут иметь положительное влияние, поскольку длительное пребывание главы правительства на посту может привести к злоупотреблению властью.
\end{abstract}

Ключевые слова: политическая нестабильность, экономический рост, панельные данные, индекс экономической свободы, валовое накопление капитала, государственные расходы, рост населения, инфляция, открытость торговли

Для цитирования: Жела А., Хиса Э. Влияние политической нестабильности на экономический рост в странах Центральной и Восточной Европы // Экономика региона. 2021. Т. 17, вып. 2. С. 582-592. https://doi.org/10.17059/ ekon.reg.2021-2-16

\section{Introduction}

The concept of political instability is difficult to be defined and measured in a way that can be used by empirical research. According to Alesina \& Perotti [1, p. 1205], "Political instability can be viewed in two ways. The first one indicates the uncertainty and instability related to executive instability and the second one is related to social unrest and political violence”. Jong-A-Pin [2] also highlights the difficulty in measuring political instability and its different dimensions. Therefore, to account for its dimensionality, the author analysed the phenomenon by conducting an explanatory factor analysis on 26 different dimensions.

The effect of political instability on economic performance is a widely discussed topic among economists and policymakers. The uncertainty associated with political instability creates an unfavourable environment for investment and economic growth. A politically unstable environment leads to frequent changes in policies, which cause volatility and negatively affect the macroeconomic performance of the economy. The Central and Eastern European (CEE) region has experienced a radical change from centrally planned to the market economy. Changes in the politi- cal, social and economic environment are associated with many issues: although some of these countries have made great progress towards democracy and market economy, they are characterised by political instability, corruption, institutional ineffectiveness, etc. Consequently, when considering these elements, it is worth questioning, "What is the impact of political instability on economic growth in transition countries of CEE?" Literature examining the impact of political instability on economic growth for this specific region is very limited. Therefore, our study aims to yield valuable results and fill this gap by conducting an empirical analysis. According to Drazen [3], there are two ways political instability affects economic growth: by negatively affecting and creating uncertainty of future returns in private investment and by reducing human capital accumulation.

A politically unstable environment is associated with rising risks, which create unfavourable conditions for investments. Alesina, Özler, Roubin \& Swagel [4] argue that political stability and economic growth are interrelated. The uncertainty connected with instability has a negative impact on the speed of economic development due to reduced investment and poor economic per- 
formance. From the other perspective, poor economic conditions might lead to governance problems. Therefore, a reverse relationship is also possible. Economic problems of a country may create pressure in the political system and become a major factor causing political instability. On the other hand, the level of economic development plays an important role in reducing uncertainty in the economic environment fostered by political instability. Mauro [5] finds that low-income countries tend to be corrupted and politically unstable.

This study takes into consideration two aspects of political instability, namely, executive instability and social unrest and political violence. The first aspect is measured by using a variable, which estimates the number of years the chief executive has been in the office, and the second one is measured by the political stability index. This index is a subjective measure of political uncertainty and violence motivated by the environment including terrorism. This index assesses the likelihood of political instability and politically motivated violence.

The structure of this paper is organised as follows. Section 2 presents the theoretical issues and findings regarding this topic. Section 3 describes an empirical model and data. Section 4 contains the empirical results of the model and section 5 concludes the paper.

\section{Theoretical Issues on Political (In)Stability and Economic Growth}

\subsection{Theoretical Framework and Discussions}

It is well-understood that political instability is not exactly the opposite of political stability, even though there are many intersections. As political instability is linked to uncertainty, and uncertainty is linked to investments and savings, it is quite understandable that, hypothetically speaking, it negatively affects economic growth $[6,7]$. Meanwhile, there are other hypotheses supporting the opposite idea that uncertainty increases investment [8]. According to our point of view, this debate is mostly associated with the profile of people and/or countries with regard to risk (risk-aversion).

Otherwise, poor performance of the economy can significantly increase political instability of certain countries $[9,10]$. Consequently, this relationship can end up in a vicious cycle, when both variables negatively affecting each other increase the possibility of a general collapse.

Discussing political stability, several authors have admitted that there are cases when political stability does not lead to increased economic growth [11]. The reasons might be different, but for example Olson [12, p. 177] states that "governments that remain in office for a long duration become easier prey for interest groups and are thus more likely to follow policies that do not maximize social welfare". Other reasons for the non-positive relation between political stability and economic growth are the high-level corruption in these countries and their potential to govern. This idea is supported by Shleifer \& Vishny [13], who argue that corruption affecting economic growth might be more dangerous in weak governments than relatively corrupt but strong governments. Furthermore, Murphy, Sleifer \& Vishny [14] emphasise the negative effects of rent-seeking activities (corruption) on economic growth. In addition, a government under threat of losing power is potentially more likely to lobby and use its position, leading to some rent-seeking actions.

Based on the above discussions and the limited literature concerning the relationship between political stability and economic growth in CEE countries, we examine whether such a relationship exists, as well as the reasons behind it. Harfst [15] in his study concludes that these countries are not that unstable, as it is possible for them to have governance stability. Using a regression analysis for Western Balkan countries, Hysa [16] revealed that the relationship between corruption and human development is strong for these groups of countries. Thus, higher corruption levels in this region are associated with low economic development. This relation is found to be stronger for Western Balkans compared to the European Union (EU) countries [17]. These high levels of corruption, for instance, in Albania, are still present because of the existing problems with the rule of law [18], which somehow, we may associate with political instability and poor government performance.

\subsection{Literature Review on Political (In)Stability and Economic Growth}

In the last decade, various studies have been investigating the link between political uncertainty and economic performance. Most of the existing literature examines instability rather than stability of economic performance. Nevertheless, different authors highlight the importance of political stability in economic growth. Political stability creates a suitable environment for economic prosperity and favourable conditions for investment, business growth, and employment. Ahmed \& Pulok [19] examined the role of political stability in economic development for the case of Bangladesh during the period 1984-2004. To in- 
vestigate the long-run effect, the Engle-Granger method of cointegration and Bound testing approach were used. Their findings suggest that stability has a negative effect on economic performance in the long run, while in the short run it has positive effects. A similar study was conducted by Nomor \& Iorember [20] for the case of Nigeria covering the period from 1999 to 2004 and using the autoregressive distributed lag (ARDL) approach. The authors conclude that stability of the political environment is an essential element of economic growth and Nigeria should search for and identify the roots of instability. Radu [21] also studied the political stability effect on economic growth and tried to define the importance of this factor in maintaining continuous sustainable economic growth. The period of analysis is from 1990 to 2011. A correlation matrix and six multivariate equations were used to analyse the impact of selected variables on economic growth. Uddin \& Masih [22] highlighted the importance of political stability using a dynamic Generalised Method of Moment (GMM) and quantile regression in a dataset composed of 120 developing countries. The main research purpose was to investigate the impact of political stability and instability in countries with different level of income for the Organisation of Islamic Conference (OIC) countries and non-OIC countries.

Political instability, on the other hand, creates uncertainty for the future, reduces human and physical capital accumulation, as well as negatively affects the development of technologies by discouraging firms and people from investing more time and money in research and development activities. Aisen \& Veiga [23] investigated the effect of this phenomenon on economic growth for a sample of 169 countries covering the period from 1960 to 2004 using a GMM estimator. They discovered that a higher degree of instability is associated with lower gross domestic product (GDP) per capita. In an early study, Compton, Giedeman \& Johnson [24] took a different approach by considering the contribution of formal and informal institutions to economic growth. Simultaneously, Tang \& Abosedra [25] examined this phenomenon along with tourism and energy consumption in the Middle East and North African countries (MENA). The authors concluded that an increase in energy consumption and tourism increases economic growth, whereas political instability reduces it. In addition, political instability affects the growth of the country by increasing the activity of the informal economy. Elbahnasawy, Ellis \& Adom [26] provided an empirical analysis where political instability and po- larisation measured by social division among ethnic and religious groups increases activity in the informal economy which negatively affects economic growth.

Other authors address this issue by including investment in their empirical analysis. Campos \& Nugent [27] found a positive causal effect going from social and political instability to investment that is relatively strong in low-income countries. Using data from 1960 for 94 countries, a social and political instability (SPI) index was constructed. The findings of this study show a positive relationship between political instability and investment. A recent study conducted by Williams [28] examined the relationship between foreign direct investment (FDI) and political instability using a system of simultaneous equations and considering the theoretical framework that the relationship between FDI and economic growth is endogenous due to the fact that both variables affect each other. This study concluded that the impact of this variable is negative and significant. Zouhaier \& Kefi [29] used a balanced data panel to investigate the relationship between our two main variables and investment for the Middle East and North African region over the period of 2000 to 2009. An interaction term between investment and political instability was used to examine the effect of political uncertainty on the contribution of investment to economic growth. No effect of political instability on investment and economic development was found. Kurecic \& Kokotovic [30] studied the impact of political stability on FDI using three panel data samples (small economies, five well-developed economies, and the countries that are prone to political violence or target by terrorist attacks) by using a vector autoregressive (VAR) framework and ARDL model. The authors revealed a long-run relationship between political instability and foreign direct investment for the small economies. Abdelkader [31] used an Error-Correction Model (ECM) and annual data for the period 1972-2013 to explore the relationship between instability in the political environment and economic development in Egypt. The results indicate that the impact of political instability is negative and significant.

Based on the above-mentioned literature, we built a conceptual framework (as illustrated in Figure 1) noting the two aspect of political instability: politically motivated violence measured by the political stability index and executive instability measured by the number of years the chief executive has been in the office. In addition, other economic variables that have an impact in economic growth are included in the model. 


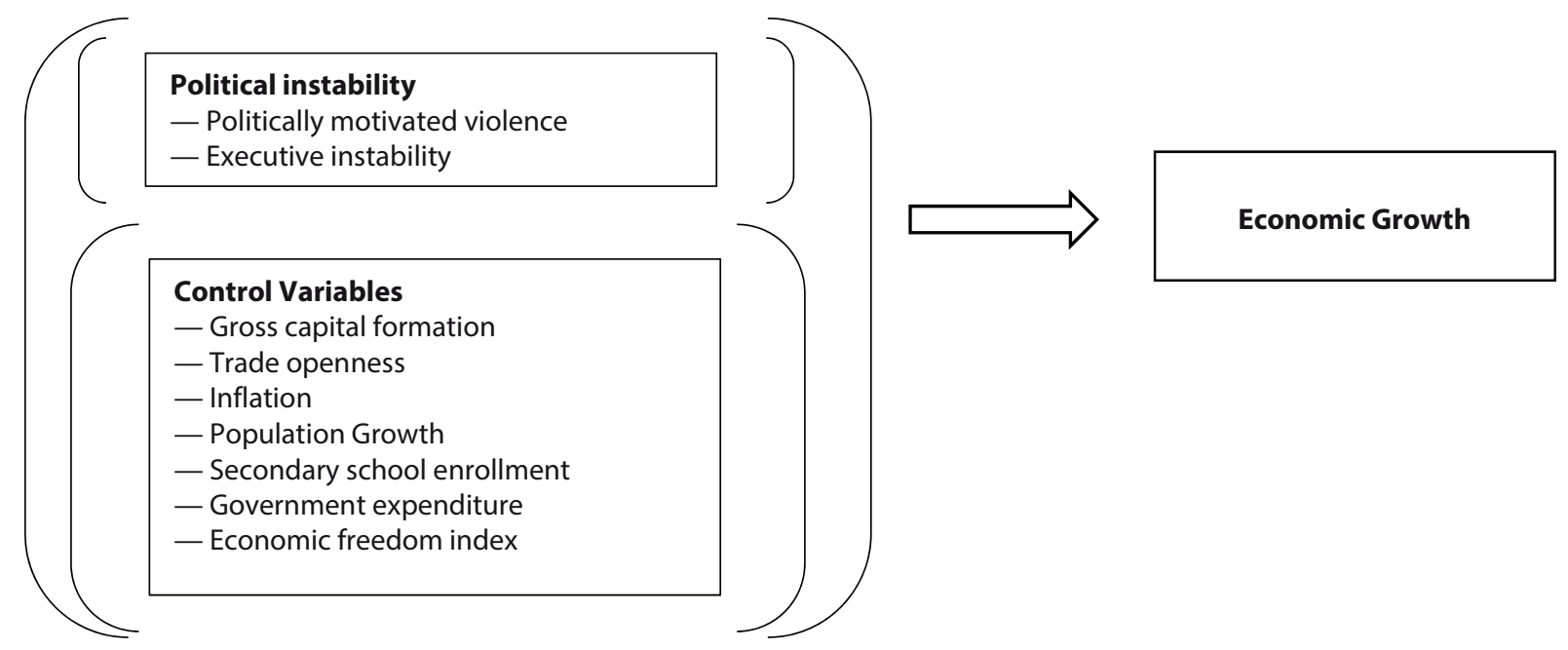

Fig. 1. Conceptual model of factors affecting economic growth

Thus, in this study, we aim to identify any obvious effect of political instability (PI) on economic growth (GDP) by using the empirical method. Based on the main objective and literature review, we analyse the following research questions and hypotheses.

As such, research questions are:

R1: What are the components of political instability according to literature?

R2: To what extent do the PI components affect the growth of GDP per capita for the case of CEE countries?

Research hypotheses state that:

H1a: Political stability index has a positive and significant impact on the growth of GDP per capita.

H1b: The indicator of the years the chief executive has been in the office has a positive and significant impact on the growth of GDP per capita.

\section{Methodology}

\subsection{Data specification}

Data employed for the empirical analysis are extracted from the World Bank database of World Development Indicators (WDI) and World Government Indicators (WGI), Database of Political Institution (DPI2017) and International Monetary Fund (IMF). For empirical analysis, we examined the period from 2006 to 2016 for 13 CEE countries: Estonia, Latvia, Lithuania, Poland, Czech Republic, Slovakia, Hungry, Romania, Bulgaria, Slovenia, Croatia, Albania, North Macedonia. For later periods, there were missing data on the selected variables such as secondary school enrolment or the variable of the years the chief executive has been in the office (Yrsoffc). Other CEE countries were also excluded due to missing data. For countries such as Serbia, Montenegro, Kosovo, and Bosnia and Herzegovina there were missing data for the economic variables and no data the variable Yrsoffc. Therefore, these countries were excluded from the study, and we considered the period from 2006 to 2016. Political instability has proven to be a challenge in measurement because it is not fully observable. Social and political instability are variables that are hard to define and measure in a way that can be used in empirical analysis. Alesina \& Perotti [1] measure political instability using different variables such as coups d'états and political assassination. Aisen \& Veiga [23] use three indexes constructed with the help of factor analysis that include such variables as cabinet changes, constitutional changes, coups, executive changes and government crises, number of legislative elections, etc.. To measure political instability, Dalyop [32], Elbargathi [33], Okafor [34] and Zouhaier \& Kefi [29] have used other proxies, including political stability and absence of violence/terrorism index of WGI. This index has been used in empirical models to assess the impact of political instability on economic growth. This composite index considers various indexes from different sources such as the Economist Intelligence Unit, the World Economic Forum, and the Political Risk Services (The Global Economy). The index indicates the probability that the government will be violently overthrown, the probability of armed conflicts, social unrest, and international terrorism. Therefore, this measure represents a good indicator of political instability in these countries, considering that data for this index is available for all the countries of the CEE region. Based on these studies, this paper extracted the data regarding the variable of political stability index from the WGI database. The WGI takes values 
from -2.5 to +2.5 representing a standard normal distribution and considers -2.5 as the highest situation of instability and +2.5 and the highest situation of stability ${ }^{1}$.

Another measure of political instability used in this study is the variable Yrsoffc that indicates years that the chief executive has been in the office. This variable is obtained from the database of political institutions 2017 of Scartascini, Cruz \& Keefer [35] and is considered as a proxy for instability related to politics. Frequent chief executive changes are a measure of regime instability. Such cabinet changes can also be accompanied by more frequent changes in policies. Therefore, they can create volatility and negatively influence economic growth. Consequently, a coefficient of the variable might have a positive sign. However, CEE countries have experienced socialism in the past, where one party and one ruler had political power for very long periods. Therefore, strong opposition and cabinet changes can be seen as a way to increase competition and make governments responsible and accountable. In this case, a negative impact of this variable is also possible. Both measures of political instability account for two aspects of it as stated in the definition Alesina \& Perotti [1, p. 1205], namely, executive instability and politically motivated violence.

Additionally, other variables that are considered to have an impact on economic growth are included in the analysis. There are two types of variables used in the empirical model: the first type of variables includes data measuring political and institutional environment; the second category comprises variables that measure macroeconomic performance such as gross capital formation, inflation, trade openness, etc.

Gross capital formation as a percentage of GDP. In literature, investments are considered a key element of economic growth. It is commonly accepted that the process of economic growth and investment are closely interconnected. Therefore, this variable is expected to have a positive impact on the growth of GDP per capita.

Trade openness. There is a large body of literature explaining the relationship between trade openness and economic development [36, 37, 38]. The debate among economists on the link and impact of trade openness is still open. However, in the long run, it is generally accepted that countries more outward-oriented enjoy a higher eco-

\footnotetext{
1 The World Bank. (2018). World Government Indicators, Retieved from: https://databank.worldbank.org/source/worldwide-governance-indicators (Date of access: 01.05.2018).
}

nomic performance. Therefore, a positive coefficient of this variable is expected.

Inflation. In all countries, one of the main objectives is to sustain economic growth together with low inflation. The relation between economic growth and prices has been shown to be quite complex. Different empirical studies have demonstrated that the relationship between economic growth and inflation can be negative, positive or non-existent. According to Tobin [39], inflation is beneficial to the economy because it lowers interest rates and, therefore, the cost of investment, which increases the capital intensity into a capital-labour ratio and output. Mallik \& Chowdhury [40] and Vladi \& Hysa [41] also revealed a positive relationship between inflation and economic growth, arguing that economies need inflation for growth but to a stable rate. In contrast, studies conducted by other authors such as Fisher [42] and Barro [43] found a negative relationship between inflation and economic growth. The variable used in this study is the average consumer price index, annual percent change obtained from the IMF.

Population growth rate. This variable drawn from the World Bank represents the annual percentage of population growth. The ideas regarding the impact of the variable are quite controversial. Economists are divided between two theories: one states that population growth is very important for economic development and has a positive impact, the other implies that population growth has a negative effect on economic growth due to various problems, such as exploitation of resources [44].

Secondary gross enrolment ratio. This variable extracted from the WDI database is a measure of secondary school enrolment for all age groups of the population to the age group that corresponds to the secondary level of education. Secondary education means the basic education that individuals receive after primary level ${ }^{2}$. There is a large body of literature explaining the impact of education on economic growth. Education is seen as an important instrument for economic growth, rising income at the private level, reducing poverty, increasing innovation, etc. [45]. Therefore, a positive value is expected for the coefficient of this variable.

Government expenditure. This variable is a measure of government final consumption expenditures drawn from the WDI database; it in-

\footnotetext{
2 The World Bank. (2018). World Government Indicators. Retrieved from: https://databank.worldbank.org/source/worldwide-governance-indicators (Date of access: 01.05.2018)
} 
Table 1

Variables description and their source

\begin{tabular}{|l|l|l|c|}
\hline \multicolumn{1}{|c|}{ Variables } & \multicolumn{1}{|c|}{ Data source } & \multicolumn{1}{|c|}{ Definition } & Expected impact \\
\hline $\begin{array}{l}\text { Real growth of GDP per } \\
\text { capita }\end{array}$ & World Bank & $\begin{array}{l}\text { The annual percentage growth rate of GDP per } \\
\text { capita }\end{array}$ & + \\
\hline Political stability index & World Bank & The index takes values from -2.5 to +2.5 & $-/+$ \\
\hline $\begin{array}{l}\text { Years chief executive has } \\
\text { been in the office }\end{array}$ & $\begin{array}{l}\text { Database } \\
\text { of political } \\
\text { institutions }\end{array}$ & $\begin{array}{l}\text { Number of years the chief executives have been in } \\
\text { the office }\end{array}$ & $\begin{array}{l}\text { Changes to the fixed assets and inventories as a } \\
\text { percentage of GDP }\end{array}$ \\
\hline Gross capital formation & World Bank & $\begin{array}{l}\text { The volume of exports and imports of goods and } \\
\text { services calculated as a percentage of GDP }\end{array}$ & + \\
\hline Trade openness & World Bank & Annual change in average consumer price index. & $-/+$ \\
\hline Inflation & WMF & Annual percentage of population growth & $-/+$ \\
\hline Population growth rate & World Bank \\
\hline $\begin{array}{l}\text { Secondary school } \\
\text { enrolment ratio }\end{array}$ & World Bank & $\begin{array}{l}\text { Annual secondary school enrolment as a percentage } \\
\text { of gross enrolment }\end{array}$ & + \\
\hline Government expenditure & World Bank & $\begin{array}{l}\text { General government final consumption expenditure } \\
\text { as a percentage of GDP }\end{array}$ & - \\
\hline $\begin{array}{l}\text { Index of economic } \\
\text { freedom }\end{array}$ & $\begin{array}{l}\text { The heritage } \\
\text { foundation }\end{array}$ & The index ranges from 0 to 100 & + \\
\hline
\end{tabular}

cludes all government current expenses for goods and services, calculated as a percentage of GDP.

Index of economic freedom. This index is based on 12 factors grouped in four main categories: rule of law (property rights, government integrity, judicial effectiveness), government size (government spending, tax burden, fiscal health), regulatory efficiency (business freedom, labour freedom, monetary freedom), and open markets (trade freedom, investment freedom, financial freedom) ${ }^{1}$.

\subsection{Model}

The model used in this paper is a fixed effects model. The fixed effects model is defined as

$$
Y_{i t}=\beta_{1} X_{i t}+a_{i}+u_{i} t=1,2, \ldots, T,
$$

where $a_{i}$ is the unobserved fixed effect over time. From the above equation, the average over time is taken for each $i$.

$$
\bar{Y}_{i t}=\beta_{1} \bar{X}_{i t}+a_{i}+\bar{u}_{i}
$$

and afterward, the difference between the first and the second equation gives:

$$
Y_{i t}-\bar{Y}_{i t}=\beta_{1} X_{i t}-\beta_{1} \bar{X}_{i t}+u_{i}-\bar{u}_{i},
$$

which is the fixed effects model. The important thing about this equation is that the unobserved fixed effect $a_{i}$ has been eliminated. Therefore, a fixed effects model allows the unobserved fixed effect $a_{i}$ to be correlated with any of the explana-

\footnotetext{
1 The Foundation Heritage. (2018). Retrieved from: https:// www.heritage.org/index/ (Date of access: 01.05.2018).
}

tory variables. A fixed effect transformation is also called the within transformation.

Before including all variables in the regression and analysing their impact on the growth of GDP per capita, we constructed a correlation matrix of all variables, presented in Table 2.

\section{Results}

Results are based on panel data covering an 11year period for CEE countries. Our dependent variable is the growth of GDP per capita, the control variables are gross capital formation, trade openness, inflation, population growth, education, and government expenditure. To measure political instability, we used an indicator of executive instability, namely, the number of years the chief executive has been in office, as well as the political stability index, which is a measure of politically motivated violence. Additionally, the index of economic freedom is used. The empirical model is the fixed effects model, confirmed by the Hausman test, and the empirical method appropriate for the available dataset is the panel data.

Results regarding the variables used as proxies for political instability show that there is no significant impact of the political stability index on the growth of GDP per capita. The variable of Yrsoffc appears to be significant only at $10 \%$ level of significance. The sign of the political stability index is positive as hypothesised, while Yrsoffc shows a negative sign.

In addition, the empirical results show that gross capital formation is significant at $1 \%$ level and has a positive coefficient as predicted by the 
Table 2

Correlation matrix of variables

\begin{tabular}{|c|c|c|c|c|c|c|c|c|c|c|}
\hline & 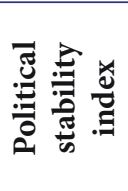 & $\underset{\mathscr{E}}{\mathscr{0}}$ & 苍㐫 & 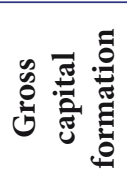 & 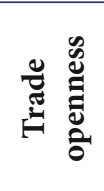 & 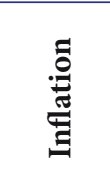 & 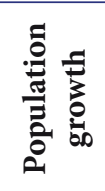 & 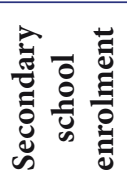 & 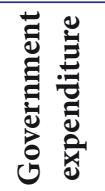 & 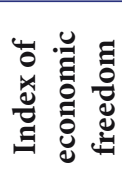 \\
\hline $\begin{array}{l}\text { Political stability } \\
\text { index }\end{array}$ & 1 & & & & & & & & & \\
\hline Yrsoffc & -0.168 & 1 & & & & & & & & \\
\hline $\begin{array}{l}\text { Growth of GDP per } \\
\text { capita }\end{array}$ & -0.050 & -0.060 & 1 & & & & & & & \\
\hline $\begin{array}{l}\text { Gross capital } \\
\text { formation }\end{array}$ & -0.253 & 0.040 & 0.458 & 1 & & & & & & \\
\hline Trade openness & 0.518 & -0.044 & 0.045 & -0.220 & 1 & & & & & \\
\hline Inflation & -0.051 & -0.038 & 0.123 & 0.550 & -0.115 & 1 & & & & \\
\hline Population growth & 0.257 & 0.011 & -0.180 & 0.022 & 0.163 & -0.167 & 1 & & & \\
\hline $\begin{array}{l}\text { Secondary school } \\
\text { enrolment }\end{array}$ & 0.500 & 0.085 & -0.059 & -0.352 & 0.324 & -0.134 & -0.251 & 1 & & \\
\hline $\begin{array}{l}\text { Government } \\
\text { expenditure }\end{array}$ & 0.578 & -0.110 & -0.326 & -0.394 & 0.487 & -0.006 & 0.227 & 0.330 & 1 & \\
\hline $\begin{array}{l}\text { Index of economic } \\
\text { freedom }\end{array}$ & 0.213 & 0.157 & -0.020 & -0.021 & 0.548 & -0.029 & -0.131 & 0.388 & 0.131 & 1 \\
\hline
\end{tabular}

Panel data results

\begin{tabular}{|c|c|c|c|}
\hline VARIABLES & Growth of GDP per capita & Growth of GDP per capita & Growth of GDP per capita \\
\hline \multirow{2}{*}{ L. GDP growth per capita } & -0.0982 & -0.0808 & -0.0953 \\
\hline & -0.0935 & -0.105 & -0.0902 \\
\hline \multirow{2}{*}{ Political stability index } & - & 1.438 & 1.42 \\
\hline & - & -2.029 & -1.677 \\
\hline \multirow{2}{*}{ Yrsoffc } & $-0.311^{*}$ & - & $-0.311^{*}$ \\
\hline & -0.146 & - & -0.144 \\
\hline \multirow{2}{*}{ Trade openness } & $0.149^{* * *}$ & $0.138^{* * *}$ & $0.150^{* * *}$ \\
\hline & -0.048 & -0.0444 & -0.048 \\
\hline \multirow{2}{*}{ Government expenditure } & -0.823 & $-0.987^{*}$ & -0.775 \\
\hline & -0.495 & -0.487 & -0.517 \\
\hline \multirow{2}{*}{ Inflation } & $-0.265^{*}$ & -0.22 & $-0.268^{*}$ \\
\hline & -0.129 & -0.155 & -0.129 \\
\hline \multirow{2}{*}{ Gross capital formation } & $0.692^{* * *}$ & $0.639^{* * *}$ & $0.693^{* * *}$ \\
\hline & -0.173 & -0.184 & -0.174 \\
\hline \multirow{2}{*}{ Population growth } & -2.131 & -2.891 & -2.172 \\
\hline & -1.739 & -1.71 & -1.71 \\
\hline \multirow{2}{*}{ Economic freedom } & -0.246 & -0.213 & -0.248 \\
\hline & -0.254 & -0.252 & -0.254 \\
\hline \multirow{2}{*}{ Secondary school enrolment } & 0.163 & 0.131 & 0.164 \\
\hline & -0.118 & -0.122 & -0.116 \\
\hline \multirow{2}{*}{ Constant } & -16.55 & -12.31 & -18.2 \\
\hline & -26.34 & -27.32 & -27.54 \\
\hline Observations & 127 & 128 & 127 \\
\hline Number of id & 13 & 13 & 13 \\
\hline R-squared & 0.627 & 0.614 & 0.629 \\
\hline Method & $\mathrm{FE}$ & $\mathrm{FE}$ & $\mathrm{FE}$ \\
\hline \multicolumn{4}{|c|}{ Robust standard errors in parentheses } \\
\hline \multicolumn{4}{|l|}{${ }^{* * *} p<0.01,{ }^{* *} p<0.05,{ }^{*} p<0.1$} \\
\hline
\end{tabular}


literature. The trade openness coefficient also has a positive and significant value at $1 \%$ level. The sign of the coefficient of inflation is negative; it is statistically significant at $10 \%$ level of significance. Population growth has a negative but not significant impact. Government expenditure also is negative and weakly significant, while secondary school enrolment is positive but insignificant.

Index of economic freedom is found to negatively affect GDP growth. This result is significant and surprising. According to the literature, the inverse relationship of these two variables is often possible, given the nature of this index, which has 12 components, each of them having different impacts on the growth of GDP per capita. Thus, an aggregated index makes it difficult to draw conclusions [46].

\section{Conclusions}

This study provides an investigation on the relationship between political instability and economic growth for the period from 2006 to 2016 in thirteen CEE countries using the fixed effects model. The aim of the study was to examine the impact of political instability on economic growth for transition countries of the CEE region. While political instability is a wide phenomenon, it is difficult to be defined and measured. Trying to account for two aspects of political instability (executive instability and political motivated unrest and violence), we use such measures as (1) the political stability index and (2) the number of years the chief executive has been in the office. In a sample of thirteen CEE countries, the political stability index is positively affecting the economic growth. However, the empirical analysis could not support the statistical significance of this result. The estimated model also showed a significant and negative impact of the second variable measuring the years the chief executive has been in the office. In this case, we found a significant impact of this variable on economic growth, even though its impact appears to be a weak one. This result rejects the second hypothesis of this research paper. As indicated before, these countries have a communist legacy, and the transition period is associated with underdeveloped institutions and corruption. Therefore, cabinet changes mean changes in the executive power and an increase in competition and accountability from the executive leaders. Considering this result, we conclude that holding power for a long time by the chief executive has a negative impact on economic growth in countries of this region. This situation might be explained by the idea that the more a chief executive is in the same position, the more connections they are supposed to have, and the easier the corruptive actions may occur. This finding helps us understand that for these countries different from what Aisen \& Veiga [23] revealed, frequent changes in executive power have a positive effect on economic growth, contributing to the literature in this field. Consistent with the study of Hysa \& Çela [47], these results seem to be extremely important because they offer some new direction and perspective regarding political stability and the necessity of cycles of change of the executive powers. In addition, other variables considered as control variables for our model, specifically, trade openness, inflation, and gross capital formation are found to be significant in explaining the growth of GDP per capita.

To conclude, this study examined debates and literature findings on the role of political stability in economic growth. The research findings remain crucial for the CEE region since they recognised and emphasised some issues, namely, the longterm stay of executive leaders at the same managing position, which negatively impacts the economy of this region. Simultaneously, the significance of the political stability index could not be confirmed, even though its impact was found to be positive. For future studies, a longer period of observations would bring new insights into this area of research for the CEE region.

\section{References}

1. Alesina, A. \& Perotti, R. (1996). Income distribution, political instability, and investment. European economic review, 40(6), 1203-1228. DOI http:// dx.doi.org/10.1016/0014-2921(95)00030-5.

2. Jong-A-Pin, R. (2009). On the measurement of political instability and its impact on economic growth. European Journal of Political Economy, 25(1), 15-29. https://doi.org/10.1016/j.ejpoleco.2008.09.010.

3. Drazen, A. (2002). Political economy in macroeconomics. Princeton University Press, 792.

4. Alesina, A., Özler, S., Roubini, N. \& Swagel, P. (1996). Political instability and economic growth. Journal of Economic growth, 1(2), 189-211.

5. Mauro, P. (2002). The persistence of corruption and slow economic growth. IMF Working Paper, No. 213, November, 23.

6. Rodrik, D. (1991). Policy uncertainty and private investment in developing countries. Journal of Development Economics, 36(2), 229-242. DOI: https://doi.org/10.1016/0304-3878(91)90034-S.

7. Goodrich, S. N. (1992). Political Instability as a Determinant of US Foreign Direct Investment Flows 1966-1982. Doctoral dissertation. Harvard University. 
8. Hartman, R. (1976). Factor demand with output price uncertainty. The American Economic Review, 66(4), 675-681.

9. Alesina, A. \& Rosenthal, H. (1995). Partisan politics, divided government, and the economy. Cambridge University Press, 300.

10. Londregan, J. B. \& Poole, K. T. (1990). Poverty, the coup trap, and the seizure of executive power. World politics, 42(2), 151-183. DOI: https://doi.org/10.2307/2010462.

11. Asteriou, D. \& Price, S. (2001). Political instability and economic growth: UK time-series evidence. Scottish Journal of Political Economy, 48(4), 383-399. DOI: https://doi.org/10.1111/1467-9485.00205.

12. Olson, M. (1982). The Rise and Decline of Nations: Economic Growth, Stagnation and Social Rigidities. New Haven: Yale University Press, 273.

13. Shleifer, A. \& Vishny, R. W. (1993). Corruption. The quarterly journal of economics, 108(3), 599-617. DOI: https:// doi.org/10.2307/2118402.

14. Murphy, K. M., Shleifer, A. \& Vishny, R. W. (1991). The allocation of talent: Implications for growth. The quarterly journal of economics, 106(2), 503-530. DOI: https://doi.org/10.2307/2937945.

15. Harfst, P. (2000). Government stability in Central and Eastern Europe: The impact of parliaments and parties. In: ECPR joint session of workshops, Vol. 14 (p. 19). Copenhagen.

16. Hysa, E. (2011). Corruption and human development correlation in Western Balkan countries. Euro Economica, 4(30), 148-157.

17. Hysa, E. (2011). Corruption and human development: Albania and EU-27. Social Studies Journal, 5(2), 43-52.

18. Pici, E., Pasmaciu, J., Hysa, E., Hoxhaj, J. \& Hodo, M. (2014). Evaluation of Millennium Development Goals Process: Case of Albania. Mediterranean Journal of Social Sciences, 5(14), 33-40. DOI: https://doi.org/10.5901/mjss.2014.v5n14p33.

19. Ahmed, M. U. \& Pulok, M. H. (2013). The role of political stability on economic performance: the case of Bangladesh. Journal of Economic Cooperation \& Development, 34(3), 61-100.

20. Nomor, T. D. \& Iorember, P. T. (2017). Political Stability and Economic Growth in Nigeria. IOSR Journal of Economics and Finance (IOSR-JEF), 8(2), 45-53.

21. Radu, M. (2015). Political stability-a condition for sustainable growth in Romania? Procedia Economics and Finance, 30, 751-757. DOI: https://doi.org/10.1016/S2212-5671(15)01324-6.

22. Uddin, M. A., Ali, M. H. \& Masih, M. (2017). Political stability and growth: An application of dynamic GMM and quantile regression. Economic Modelling, 64, 610-625. DOI: https://doi.org/10.1016/j.econmod.2017.04.028.

23. Aisen, A. \& Veiga, F. J. (2013). How does political instability affect economic growth? European Journal of Political Economy, 29, 151-167. DOI: https://doi.org/10.1016/j.ejpoleco.2012.11.001.

24. Compton, R. A., Giedeman, D. C. \& Johnson, N. D. (2006). Political Instability, Institutions, and Economic Growth. Preliminary draft presented at XIV International Economic History Congress. Helsinki.

25. Tang, C. F. \& Abosedra, S. (2014). The impacts of tourism, energy consumption and political instability on economic growth in the MENA countries. Energy Policy, 68, 458-464. DOI: https://doi.org/10.1016/j.enpol.2014.01.004.

26. Elbahnasawy, N. G., Ellis, M. A. \& Adom, A. D. (2016). Political instability and the informal economy. World Development, 85, 31-42.

27. Campos, N. F. \& Nugent, J. B. (2003). Aggregate investment and political instability: An econometric investigation. Economica, 70(279), 533-549. DOI: https://doi.org/10.1111/1468-0335.01081.

28. Williams, K. (2017). Foreign direct investment, economic growth, and political instability. Journal of economic development, 42(2), 17-37.

29. Zouhaier, H. \& KEFI, M. K. (2012). Interaction between political instability and investment. Journal of Economics and International Finance, 4(2), 49-54.

30. Kurecic, P. \& Kokotovic, F. (2017). The relevance of political stability on FDI: A VAR analysis and ARDL models for selected small, developed, and instability threatened economies. Economies, 5(3), 1-22.

31. Abdelkader, H. E. M. (2017). Political instability and economic growth in Egypt. Review of Middle East Economics and Finance, 13(2), 1-11.

32. Dalyop, G. T. (2019). Political instability and economic growth in Africa. International Journal of Economic Policy Studies, 13(1), 217-257. DOI: https://doi.org/10.1007/s42495-018-0008-

33. Elbargathi, K. (2019). The Impact of Political Instability on the Economic Growth: An Empirical Analysis for the Case of Selected Arab Countries. International Journal of Business and Economics Research, 8(1), 14-22. DOI: https://doi. org/10.11648/j.ijber.20190801.13

34. Okafor, G. (2017). The impact of political instability on the economic growth of ECOWAS member countries. Defence and Peace Economics, 28(2), 208-229. DOI: https://doi.org/10.1080/10242694.2015.1092206

35. Scartascini, C., Cruz, C. \& Keefer, P. (2018). The database of political institutions 2017 (DPI2017). Retrieved from: https://publications.iadb.org/en/database-political-institutions-2017-dpi2017 (Date of access: 01.05.2018)

36. Yanikkaya, H. (2003). Trade openness and economic growth: a cross-country empirical investigation. Journal of Development economics, 72(1), 57-89. DOI: https://doi.org/10.1016/S0304-3878(03)00068-3.

37. Fetahi-Vehapi, M., Sadiku, L. \& Petkovski, M. (2015). Empirical analysis of the effects of trade openness on economic growth: An evidence for South East European Countries. Procedia Economics and Finance, 19, 17-26.

38. Idris, J., Yusop, Z. \& Habibullah, M. S. (2016). Trade openness and economic growth: a causality test in panel perspective. International Journal of Business and Society, 17(2), 281-290. DOI: https://doi.org/10.33736/ijbs.525.2016. 
39. Tobin, J. (1965). Money and economic growth. Econometrica: Journal of the Econometric Society, 33, 671-684.

40. Mallik, G. \& Chowdhury, A. (2001). Inflation and economic growth: evidence from four south Asian countries. AsiaPacific Development Journal, 8(1), 123-135.

41. Vladi, E. \& Hysa, E. (2019). The impact of macroeconomic indicators on unemployment rate: Western Balkan countries. In: International firms' economic nationalism and trade policies in the globalization era (pp. 158-181). IGI Global.

42. Fischer, S. (1993). The role of macroeconomic factors in growth. Journal of monetary economics, 32(3), $485-512$. DOI: https://doi.org/10.1016/0304-3932(93)90027-D.

43. Barro, R. J. (1995). Inflation and economic growth (No. w5326). National bureau of economic research, 14(1), 121144.

44. Obere, A., Thuku, G. K. \& Gachanja, P. (2013). The Impact of Population Change on Economic Growth in Kenya. International Journal of Economics \& Management Sciences, 2(6), 43-60.

45. Hanif, N. \& Arshed, N. (2016). Relationship between school education and economic growth: SAARC countries. International Journal of Economics and Financial Issues, 6(1), 294-300.

46. Borovic, Z. (2014). Does Economic Freedom Impact Economic growth: Decomposing the Effects for Bosnia and Herzegovina. Acta Economica, 12(21), 9-20. DOI: https://doi.org/10.7251/ACE1421009B.

47. Hysa, E. \& Çela, A. (2019). Relationship between Governance and Human Development in European Countries: Panel Regression Analysis. In: The 2019 IAI Academic Conference Proceedings (pp. 59-70). Rome, Italy.

\section{About the authors}

Arjona Çela - PhD Candidate in Economics, Research Assistant, Department of Economics, Epoka University; https:// orcid.org/0000-0001-6201-2152 (Tirana, Albania; e-mail: acela@epoka.edu.al).

Eglantina Hysa - Assoc. Prof. Dr., Lecturer of Economics, Department of Economics, Epoka University; https://orcid. org/0000-0002-3429-5738 (Tirana, Albania; e-mail: ehysa@epoka.edu.al).

\section{Информация об авторах}

Жела Арйона - PhD кандидат в области экономики, научный сотрудник, факультет экономики, Университет Эпока; https://orcid.org/0000-0001-6201-2152 (Тирана, Албания; e-mail: acela@epoka.edu.al).

Хиса Эглантина - доктор экономики, доцент, преподаватель экономики, факультет экономики, Университет Эпока; https://orcid.org/0000-0002-3429-5738 (Тирана, Албания; e-mail: ehysa@epoka.edu.al).

Дата поступления рукописи: 03.04.2020.

Прошла рецензирование: 25.06.2020.

Принято решение о публикаиии: 23.03.2021.

Received: 03 Apr 2020

Reviewed: 25 Jun 2020

Accepted: 23 Mar 2021 